\title{
North American Glyptodontines (Xenarthra, Mammalia) in the Upper Pleistocene of northern South America
}

\author{
Alfredo A. Carlini, La Plata; Alfredo E. Zurita, La Plata \& Orangel A. Aguilera, Coro
}

with 4 figures

CARlini, A.A.; ZURitA, A.E. \& AGUILera, O.A. 2008. North American Glyptodontines (Xenarthra, Mammalia) in the Upper Pleistocene of northern South America. - Paläontologische Zeitschrift 82 (2): 125-138, 4 figs., Stuttgart, 30. 6. 2008.

\begin{abstract}
The Glyptodontidae is one of the most conspicuous groups in the Pleistocene megafauna of the Americas. The Glyptodontinae were involved in the Great American Biotic Interchange (GABI) and their earliest records in North America are about $3.9 \mathrm{Ma}$, suggesting an earlier formation of the Panamanian landbridge. Taxonomically it is possible to recognize two Pleistocene genera of Glyptodontinae: Glyptodon (ca. $1.8-0.008 \mathrm{Ma}$ ), restricted to South America, and Glyptotherium (ca. 2.6-0.009 Ma), including records in both North and Central America. Here we present the first report of the genus Glyptotherium in South America, from the Late Pleistocene of several fossil localities in Falcón State, northwestern Venezuela. A comparative analysis of the material, represented by cranial and postcranial parts, including the dorsal carapace and caudal rings, suggests a close affinity with Glyptotherium cylindricum (Late Pleistocene of Central Mexico). This occurrence in the latest Pleistocene of the northernmost region of South America supports the bidirectional faunal migration during the GABI and the repeated re-immigration from North America of South American clades, as has been reported in other members of the Cingulata (e.g., Pampatheriidae).
\end{abstract}

Keywords: Glyptodontidae $\bullet$ Glyptotherium $\bullet$ Pleistocene $\bullet$ South America $\bullet$ Venezuela $\bullet$ Paleobiogeography $\bullet$ Great American Biotic Interchange

Kurzfassung: Die Glyptodontidae ist eine der auffälligsten Faunengruppen des Pleistozäns Südamerikas. Die Glyptodontinae waren in dem „Great American Biotic Interchange“ (GABI) involviert, und ihre frühesten Reste aus Nordamerika sind etwa 3,9 Ma alt, was für eine frühere Entstehung der Panamanischen Landbrücke spricht. Es ist taxonomisch möglich, zwei Genera von pleistozänen Glyptodontinae zu unterscheiden: Glyptodon (ca. 1,8-0,008 Ma) aus Suidamerika und Glyptotherium (ca. 2,6 - 0,009 Ma) aus Nord- und Mittelamerika. Hier stellen wir den ersten Nachweis von Glyptotherium in Südamerika, aus dem oberen Pleistozän von verschiedenen Lokalitäten des Bundesstaates Falcón, nordwestliches Venezuela, vor. Eine vergleichende Untersuchung von Schädel- und Postkranialelementen, einschließlich des dorsalen Panzers und kaudaler Ringe, unterstützt eine nahe Verwandtschaft mit Glyptotherium cylindricum (Spätes Pleistozän Mittel-Mexikos). Diese spät-pleistozäne Verbreitung im nördlichsten Teil Südamerikas ist ein Nachweis für eine bidirektionale Migration während des GABI und für das Zurückkehren von Taxa von Nordamerika nach Südamerika, wie schon für andere Vertreter der Cingulata (z. B. Pampatheriidae) berichtet wurde.

Schlüsselwörter: Glyptodontidae • Glyptotherium • Pleistozän • Südamerika • Venezuela • Paläobiogeographie • Great American Biotic Interchange

\section{Introduction}

During the Great American Biotic Interchange (GABI), several taxa of South American mammals, such as Xenarthra and Marsupialia, migrated into North America, while North American taxa such as Cervidae, Felidae, Tapiridae, Ursidae, and Gomphotheriidae migrated into South America, by means of the biological corridor for terrestrial organisms that arose between both continents, first as an island chain and later as an unbroken

Addresses of the authors: Alfredo A. Carlini, Paläontologisches Institut und Museum, Universität Zürich, Karl Schmid-Straße 4, CH-8006 Zürich, Switzerland, and Departamento Científico Paleontología de Vertebrados, Museo de La Plata, Paseo del Bosque s/n B1900FWA La Plata, Argentina. CONICET. Cátedra de Anatomía Comparada, Facultad de Ciencias Naturales y Museo, Universidad Nacional de La Plata, Argentina; e-mail <acarlini@fcnym.unlp.edu.ar>. - Alfredo E. Zurita, Departamento Científico Paleontología de Vertebrados, Museo de La Plata, Paseo del Bosque s/n B1900FWA La Plata, Argentina y Centro de Ecología Aplicada del Litoral (CECOAL-CONICET); e-mail <aezurita74@yahoo.com.ar>. - Orangel A. Aguilera, Laboratorio de Paleoecología, Centro de Investigaciones en Ciencias Básicas, Universidad Experimental Francisco Miranda, Complejo Docente Los Perozos, Coro 4101, Estado Falcón, Venezuela; e-mail <orangel.aguilera@gmail.com>. 
terrestrial connection, starting about $5 \mathrm{Ma}$ (see WEBB 1985, 2006; PASCUAL \& WEBB 1989; PASCUAL \& ORTIZ-JAUREGUIZAR 1990; TONNI et al. 1992; PASCUAL et al. 1996; WOODBURNE et al. 2006), and ending about $2.7 \mathrm{Ma}$. The emergence and consolidation of this continuous corridor was strongly influenced by the Pliocene Diaguita phase that triggered the final uplifting of the Panama isthmus, thus allowing and facilitating the definitive biogeographical connection between North and South America (PASCUAL et al. 1996). Recently, CARRANZA-CASTAÑEDA \& MILLER (2004) and FLYNN et al. (2005) suggested that this land bridge might have originated more than one million years earlier, but not necessarily continuous in time. This hypothesis is supported by the presence of Glossotherium, Glyptotherium?, Plaina and Neochoerus [sic] in central Mexico at approximately 4.7 to $3.6 \mathrm{Ma}$.

The relationship between both Americas before that time was represented by chains of emerged lands, at least since ca. $9 \mathrm{Ma}$ (SMITH 1985; WEBB 2006). This particular condition undoubtedly exerted strong regulation on both the type and intensity of biotic migrations between these continents, with discretional or specific effects in different cases. Currently it seems evident that the entrance of taxa of Holarctic origin into South America was a more gradual process than previously assumed, given that the biomass and diversity of immigrant taxa appear to be very scarce during the Chapadmalalan and Marplatan (ca. 3.9 - $1.8 \mathrm{Ma}$ ) (TONNI et al. 1992; CIONE \& TONNI 2001) and become more evident during the Ensenadan - Lujanian (ca. 1.8 - 0.008 Ma (CIONE \& TONNI 1995a, b, 2005). In North America, the first reliable records of South American immigrants correspond to the Hemphillian (ca. $9 \mathrm{Ma}$, WEBB 2006); subsequently these records occur continuously from the late Blancan (ca. 2.7 Ma) in southwestern USA (WOODBURNE \& SWISHER 1995; MORGAN \& WHITE 2005; WHITE \& MORGAN 2005; WEBB 2006).

The Xenarthra are one of the groups of South American mammals that were actively involved in the faunal exchange, given that both the Phyllophaga (Megatheriidae, Megalonychidae and Mylodontidae) and the Cingulata (Dasypodidae, Pampatheriidae and Glyptodontidae) reached North America, and even differentiated into new taxa characteristic of the latter continent. Among the Cingulata, the glyptodontine Glyptodontidae entered North America during the early Pliocene (middle Blancan; ca. $3.9 \mathrm{Ma}$; CARranza-Castañeda \& Miller 2004; WHITE \& MORGAN 2005; MORGAN \& WHITE 2005; FLYNN et al. 2005), with the subsequent differentiation of a genus different from the South American Glyptodon OWEN (see GILLETTE \& RAY 1981).

Unlike the South American Glyptodontinae, for which no recent revision is available (SOIBELZON et al. 2006), the North American taxa were studied by GILLETTE \& RAY (1981). These authors concluded that only one genus can be recognized; based on priority, this is Glyptotherium OSBORN (= Brachyostracon
BROWN = Boreostracon SIMPSON = Xenoglyptodon MEADE), with a temporal distribution that ranges from the Pliocene to the late Pleistocene. In this taxonomic context, Carranza-Castañeda \& Miller (2004) have reported some isolated scutes from central Mexico that they referred to ?Glyptotherium, coming from sediments dated at ca. $3.9 \mathrm{Ma}$. This genus, with certainty present in North America since ca. $2.6 \mathrm{Ma}$, diversified into five described species: a) $G$. texanum OSBORN (late Blancan; late Pliocene), distributed in the southern US; b) G. arizonae GIDLEY (late Blancan - early Irvingtonian; late Pliocene - early Pleistocene), with unquestionable records in the southern US; c) $G$. floridanum (SIMPSON) (Rancholabrean; late Pleistocene), with numerous records in central-south and southeastern US, and central and central-south Mexico; d) G. mexicanum (CUATÁPARO \& RAMÍREZ) (late Rancholabrean; late Pleistocene), known only from the holotype, from central-south Mexico; and e) G. cylindricum (BROWN) (early Rancholabrean; late Pleistocene), which like the previous case is known only from the holotype, found in central-western Mexico (GILleTte \& RAY 1981).

The presence of Glyptotherium in Central America has been mentioned by WEBB \& PERRIGo (1984) for the late Pleistocene of Panama and Honduras, and by CISNEROS et al. (2001) and CISNEROS (2005) for the Pleistocene (Irvingtonian?) of El Salvador.

Until now, all the records of glyptodontine Glyptodontidae from Venezuela have traditionally been referred to the genus Glyptodon (a.o., KARSTEN 1886; RoYo Gómez 1960; CRUXENT 1967; CASAMIQUELA 1979; BOCQUENTIN VILLANUEVA 1982a, b; OCHSENIUS 1980; AGUILERA 2006), primarily on the basis of dorsal carapace osteoderms recovered from upper Pleistocene fossil beds. These remains have been alternately designated as Glyptodon clavipes (ROYO GÓMEZ 1960; OCHSENIUS 1980), G. cf. clavipes and cf. Glyptodon (CASAMIQUELA 1979; AGUILERA 2006), with variable degrees of certainty and mostly without comparative anatomical analyses to support these assignments.

A detailed study of these materials from the uppermost Pleistocene, including skulls, postcranial skeletons, dorsal carapaces and caudal rings, especially from the localities TaimaTaima, Muaco, Cucuruchú, and Quebrada Ocando in Falcón State, Venezuela (Fig. 1), indicates that all of them are in fact assignable to the genus Glyptotherium and morphologically similar to $G$. cylindricum. Consequently, this represents the first record of this North American glyptodontine genus for South America, considerably expanding its geographic distribution to $70^{\circ} \mathrm{W}$.

Even though the GABI has usually been interpreted as unidirectional migrations between both Americas through the Panama landbridge, some cases of re-entrance have been verified. Indeed, SCILLATO-YANÉ et al. (2005) recently addressed the emigration of pampatheriid Cingulata toward North America during the 


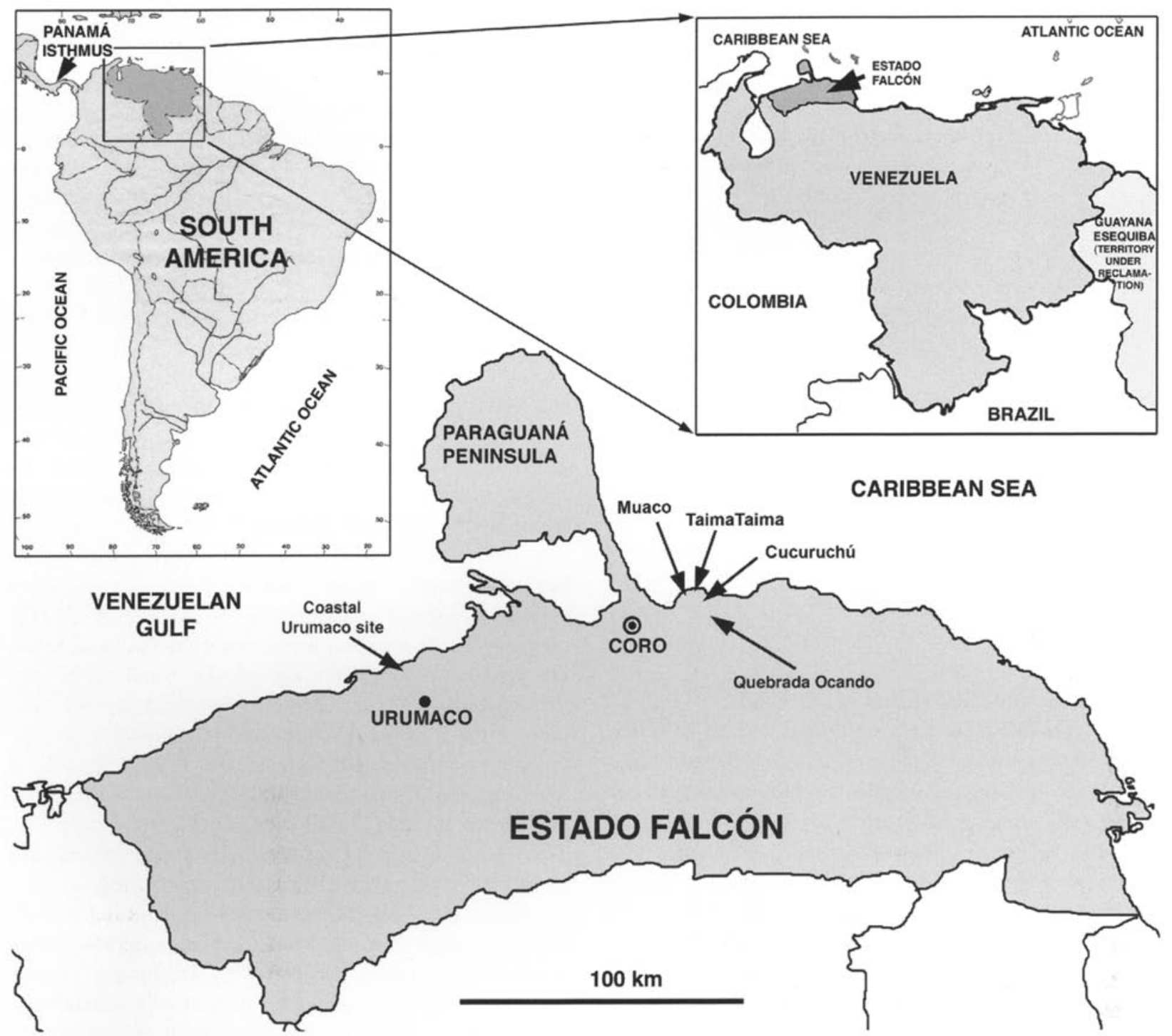

Fig. 1. Location map, showing main localities where Glyptotherium cf. cylindricum was identified among fossil remains.

late Pliocene, the latter differentiation of a new genus in North America, and its subsequent re-entrance into South America during the Pleistocene, simultaneous with a second emigration of Pampatheriidae. Within this dynamic biogeographic scenario, the presence of Glyptotherium cf. G. cylindricum, in the upper Pleistocene of the extreme northern South America is probably the second example among Xenarthra of re-entrance of fauna of South American origin that differentiated in North America and then re-entered the southern subcontinent.

This paper deals mainly with the paleobiogeography of Late Pleistocene North American Glyptodontinae, including one species, Glyptotherium cf. cylindricum BROWN, 1912, that reached South America at some time during the latest Pleistocene. We also provide support for the generic differences between Glyptotherium and Glyptodon, and provide some considerations about climate and other environmental factors that may have influenced their differentiation and their time of dispersal into South America.

\footnotetext{
Abbreviations used in the text: AMNH, American Museum of Natural History, New York, USA; GABI, Great American Biotic Interchange; $M, m$, upper and lower molariform respectively; MCN, Museo de Ciencias de Caracas, Venezuela; $\mathrm{n} / \mathbf{n}$, without official catalog number; UCV, Universidad Central de Venezuela, Caracas, Venezuela; UNEFM-CIAAP, Universidad Nacional Experimental Francisco Miranda, Coro, Venezuela - Centro de Investigaciones Antropológicas, Arqueológicas y Paleontológicas.
} 


\section{Systematic paleontology}

\author{
Xenarthra COPE, 1889 \\ Cingulata ILLIGER, 1811 \\ Glyptodontoidea GRAY, 1869 \\ Glyptodontidae GRAY, 1869 \\ Glyptodontinae GRAY, 1869 \\ Glyptotherium OSBORN, 1903
}

\section{Glyptotherium cylindricum (BROWN, 1912) sensu GILleTtE \& RAY, 1981 \\ Syn. Brachyostracon cylindricum BROWN, 1912}

Holotype: AMNH 15548, hyoid, skull fragment, atlas, fragments of ribs, 20 isolated molariforms, complete dorsal carapace and fragments of caudal rings.

Type locality and age: Area near Ameca $\left(105^{\circ} \mathrm{W}\right)$, Jalisco, Mexico (BROWN 1912); late Pleistocene sediments (see GILLETTE \& RAY 1981).

\section{Glyptotherium cf. cylindricum (BROWN, 1912) sensu GILLETTE \& RAY, 1981}

\author{
Figs. 2-3
}

\section{Description and assignation of material}

Skull: The skull (MCN n/n) of Glyptotherium cf. cylindricum from Venezuela (Figs. 2A-D) is generally similar to that of Glyptotherium texanum, Glyptotherium floridanum and Glyptotherium arizonae. It is clearly distinguished from Glyptodon munizi, Glyptodon clavipes and Glyptodon reticulatus by its greater anteroposterior elongation, greater postorbital and bizygomatic diameter, evident forward prolongation of the predental portion of the palate, and less upward inclination of the dorsal skull profile, particularly in the parieto-occipital region in lateral view.

In lateral view, the angle formed by the palatal plane and the dorsal skull profile in $G$. cf. cylindricum is much more open than in $G$. munizi and $G$. clavipes, forming an angle similar to the one in Glyptotherium texanum and G. floridanum. Consequently, the dorsal profile of $G$. cf. cylindricum is more inclined upwards and backwards than in G. munizi, and much more than in $G$. clavipes; the nasal bones are almost at the same level as the dorsal portion of the frontals and parietals. The development of the entire occipital region is similar to that of the other Glyptotherium species, but much less than that of Glyptodon. The anteroposterior development of the squamosal portion of the zygomatic arch is greater than in $G$. clavipes and similar to that of $G$. $m u$ nizi, as one of the main consequences of the greater skull elongation. The anteroposterior diameter of the orbital notch is greater than its dorsoventral diameter. This differentiates this species from $G$. arizonae, whose orbital notch has greater dorsoventral diameter and subelliptical outline. Likewise, the orbital notch of $G$. munizi, $G$. clavipes and $G$. reticulatus is almost completely circular and its anteroinferior border, formed by the uppermost part of the descending process of the maxilla and jugal, has a thickened rim that is not present in $G$. cf. $c y$ lindricum, G. arizonae or G. floridanum. Posteriorly, the orbit is freely communicated with the temporal fossa, as in Glyptodon and the Hoplophorinae, and differing from Doedicurus, in which the orbit is closed posteriorly. Anteriorly, the area comprising the alveolar portion of the maxillae is more extended anteroposteriorly than in Glyptodon, very similar to the condition observed in G. arizonae, G. texanum and G. floridanum. This greater rostral elongation is particularly evident in the predental portion of the palate that extends forward greatly in advance of the nostrils as in G. floridanum, and contrasting with Glyptodon, in which the premaxillae, maxillae, nasals, and frontals end at the same level, forming a vertical plane. As is characteristic of Pleistocene glyptodontines, the nasals and premaxillae are considerably reduced (LYDEKKER 1894; BURMEISTER 1864; SOIBELZON et al. 2006).

In frontal view, the nostrils are heart-shaped, with the upper margin wider than the lower one; they are somewhat similar to those of $G$. arizonae, and the Hoplophorinae Eosclerocalyptus proximus and Plohophorus figuratus. In Glyptodon clavipes and G. munizi these openings are clearly subtriangular, with free margins of the maxillae straight and more developed septum that separates both nasal cavities. The infraorbital foramina are at the same level as in the remaining Glyptotherium species, and show no significant differences. The orientation of the exiting infraorbital foramina is clearly anterior, as in G. clavipes, and differing from the condition of G. munizi, in which the opening of this foramen is rather laterally oriented. The descending processes of the maxillae are markedly divergent ventrally, and their internal margins are almost completely straight, as in G. arizonae. This particular morphology distinguishes this taxon from the genus Glyptodon, in which the descending processes of the maxillae are generally curved toward the sagittal plane, so that their internal margins are clearly concave.

Dorsally, the nuchal ridges at both sides of the supraoccipital are widely open, forming an angle of about $180^{\circ}$ with each other, whereas this angle is more closed, about $120^{\circ}$, in $G$. clavipes and $G$. munizi. These ridges do not form a defined sagittal ridge on the parietals near or at the skull midline, as in G. reticulatus, G. munizi and $G$. clavipes. As in all Glyptodontidae, this area presents numerous vascular and nervous foramina largely concentrated on the parietals, which are small and restricted to the dorsal region of the skull. The absence of a sagittal crest is also observable in G. arizonae. Anteriorly, the entire area demarcated by the supraoccipital ridge and the postorbital apophyses of the frontal bone is noticeably more expanded transversally than in G. clavipes, and much more so than in G. mu$n i z i$; the condition in this taxon is very similar to that of $G$. arizonae and G. texanum. This greater widening is especially evident at the level of the postorbital narrowing. The zygomatic arches form a semicircle more evi- 


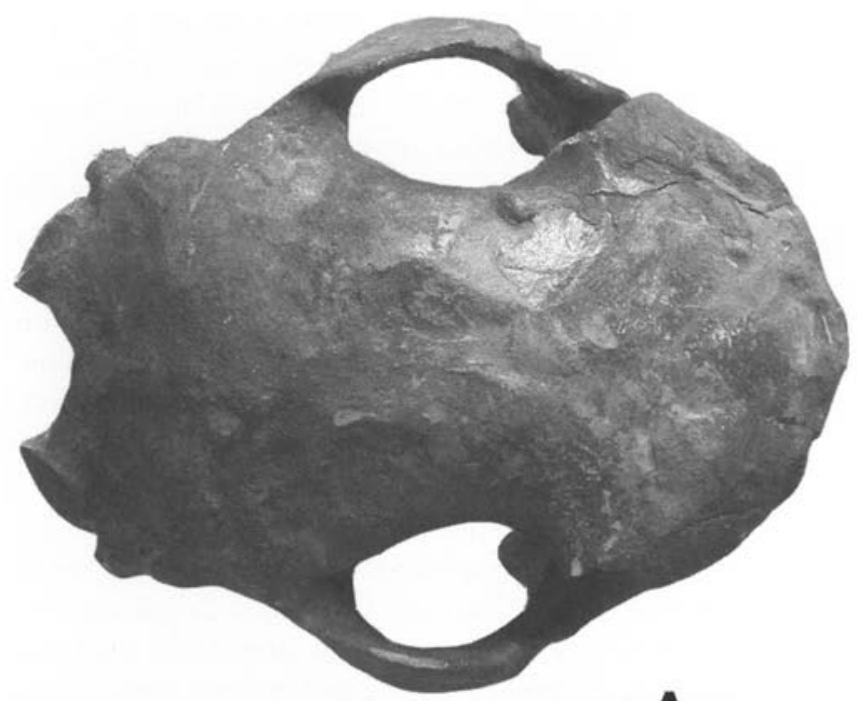

A

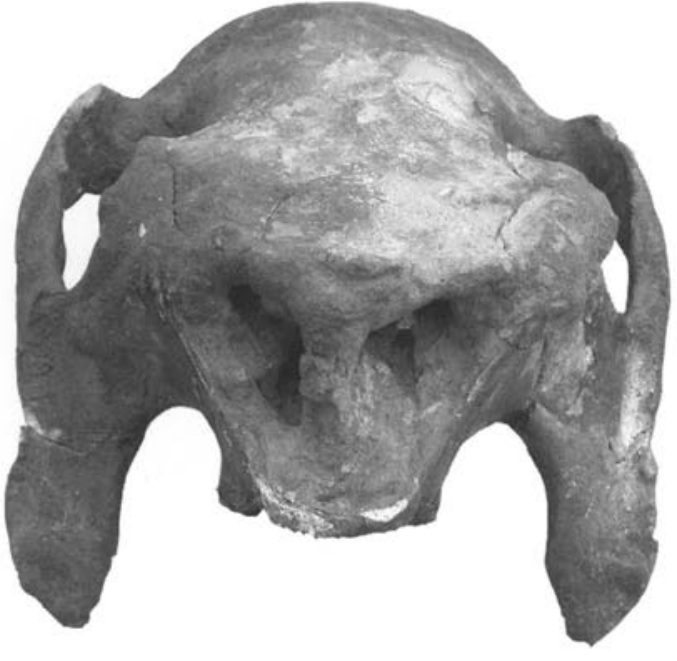

B
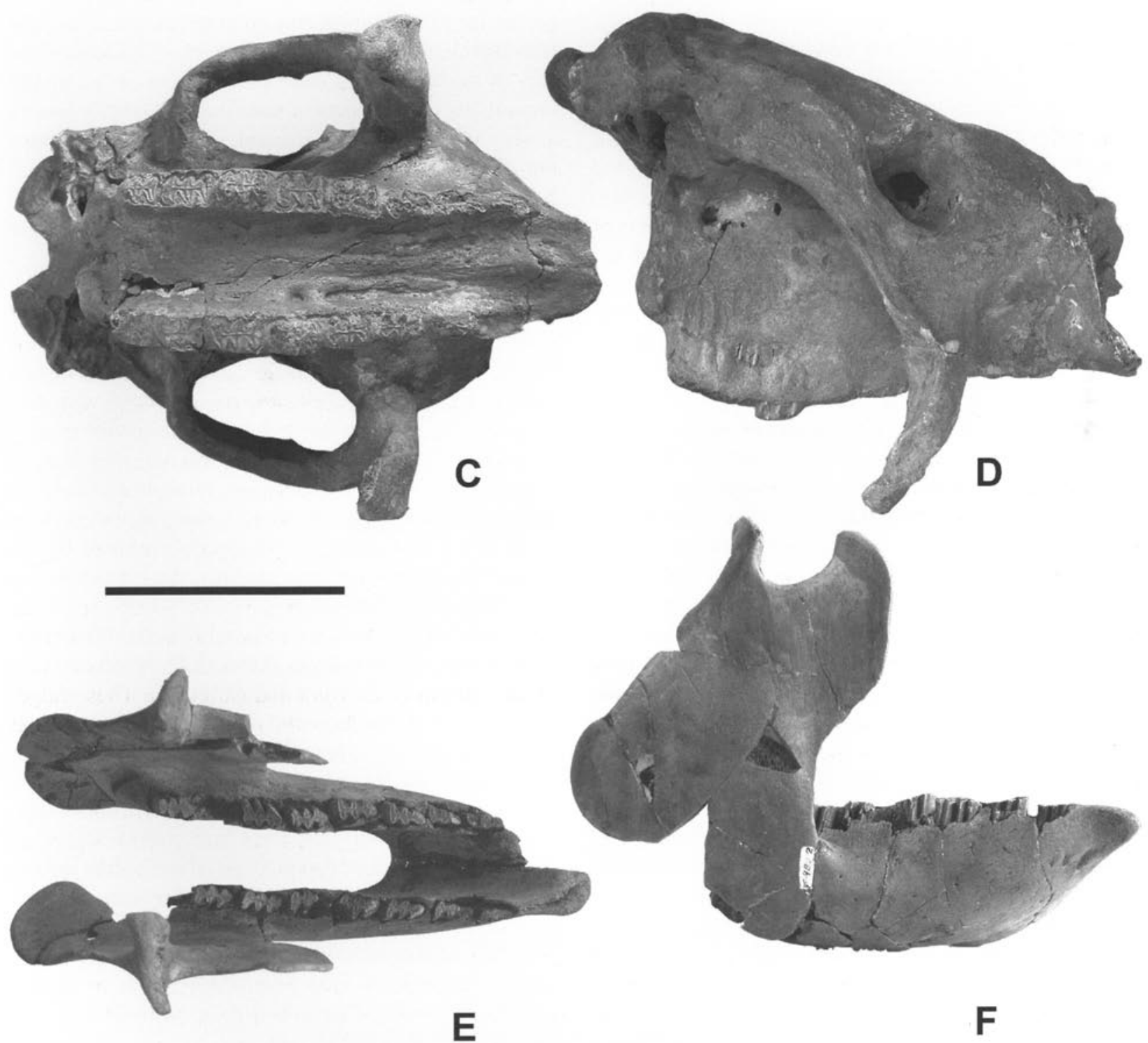

Fig. 2. Glyptotherium cf. cylindricum. A-D: Skull $(\mathrm{MCN} n / n)$ in A. dorsal; B. frontal; C. occlusal; and D. lateral view. E-F: Mandible (UCV $n / n$ ) in E. occlusal; and F. lateral view. - Scale bar $=10 \mathrm{~cm}$. 
dent than in Glyptodon, in which they tend to be straighter. The surface formed by the frontal bones is distinctly convex anteriorly to the postorbital apophyses, so that its lateral margins are also somewhat convex. This area is clearly different from that of G. munizi, $G$. reticulatus and $G$. clavipes, because it is nearly flat, and consequently presents straight lateral margins. This entire area is largely subtriangular in Glyptodon, with the apex directed toward the mid-distal end of the nasals.

The foramen magnum is oval, with its long axis transversal. In occlusal view, the palate is wide and the premaxillae are less shortened than in Glyptodon, similar to the other Glyptotherium species. Both molariform series are more separated posteriorly; this condition is especially evident at the level of M4. The predental portion of the palate, formed by the maxillae and premaxillae, is markedly extended anteroposteriorly, very similar to that of $G$. floridanum and the Hoplophorinae Eosclerocalyptus proximus, in which this area is subtriangular. This condition differs remarkably from that of Glyptodon, in which this zone is truncated and subquadrangular. Four or five large foramina open at both sides of the dental series, at the level of molariforms M4-M6. The infraorbital foramina are at the level of a plane projecting between M2 and M3, and the ventralmost point of the descending process of the maxilla coincides with a plane passing through the first lobe of M4, as in G. arizonae and G. texanum. In the posterior palate region, immediately behind M8, the small palatine bones are restricted to the lower margin of the choanal opening.

Dentition: All the upper and lower molariforms are lobed and with secondary osteodentine ramifications (Figs. 2C, E); the latter is probably a synapomorphy of Glyptodontinae. The $\mathrm{m} 1$ of $G$. cylindricum is characterized by its clear trilobation, even more marked than in the remaining Glyptotherium species, with well developed notches separating the lobes, particularly on the labial side. This differentiates this species from $G$. $m u$ $n i z i$, in which the lobation is almost nonexistent on the lingual side, and from $G$. floridanum, in which $\mathrm{ml}$ is simple and ovoid in transverse section. In G. cylindricum, bilateral development of the last lobe of $\mathrm{ml}$ is asymmetric, so that the lobe is more evident labially than lingually. The morphology of $\mathrm{m} 2$ and $\mathrm{m} 3$ is similar to that of $\mathrm{m1}$, only larger, and with the third lobe showing more asymmetric bilateral development; these teeth are somewhat similar to those of G. munizi, G. clavipes, G. arizonae, and the $\mathrm{m} 3$ of $G$. floridanum. From $\mathrm{m} 4$ to $\mathrm{m} 8$, all molariforms have the same basic morphological pattern, whereas the last lobe is inclined approximately $80^{\circ}$ degrees with respect to the sagittal plane; this condition clearly differentiates this taxon from Glyptodon, in which the transverse axis of the last lobe forms a $90^{\circ}$ angle with respect to that plane. Lastly, the third lobe is markedly smaller, as in G. floridanum. Generally, the lower dentition of $G$. cf. cylindricum is similar to that of $G$. arizonae, but can be differentiated from this taxon by presenting a less asymmetrical bilateral development, particularly in molariforms $\mathrm{m} 1-\mathrm{m} 5$.

M1 is lobed, although the notches separating the lobes are poorly developed, and the transverse axis of the first lobe is inclined $50^{\circ}$ with respect to the anteroposterior axis of the dental series. M2 is evidently trilobated; the occlusal surface of its first lobe is much more expanded labially and presents the same inclination observed in M1. The next two molariforms (M2 and M3) are similar, except that the first lobe progressively loses the original inclination and the posterior margin of the last lobe acquires a convex outline. Molariforms M4 to M8 are similar to each other; they are characterized by symmetrical bilateral development of the first lobe and by having the transverse axis perpendicular to the longitudinal axis of the dental series. In these teeth, the anterior margin of the first lobe is almost completely flat, except for M8, in which this anterior margin is slightly concave. A particular feature of $G$. cf. cylindricum occurs in the last lobe of these molariforms, in which the lingual half, more expanded than the labial half, presents a very convex internal margin; numerous secondary ramifications of vasculodentine appear in this lingual half. This is also observable in $G$. arizonae, but the reduction of the labial half of the molariform is more marked in the latter species.

Mandible: The mandible of $G$. cf. cylindricum (UCV n/ $\mathrm{n}$ ) is slender (Figs. 2E, F) and morphologically similar to that of $G$. texanum and $G$. floridanum. It differs clearly from that of Glyptodon and Glyptotherium arizonae by the much greater robustness in the latter taxa. In lateral view, the horizontal ramus is lower than in Glyptodon and Glyptotherium arizonae, and its inferior margin is slightly convex, almost straight, and parallel to the molariform series as in G. floridanum and G. texanum. This particular morphology distinguishes this taxon from the genus Glyptodon and from G. arizonae, in which the horizontal ramus is very deep, with a markedly convex ventral margin. Anterior to the $\mathrm{ml}$, the predental portion of the symphyseal region is at a level with the molariform series along its entire anteroposterior extension, and consequently its dorsal margin is horizontal and straight, whereas in Glyptodon the distalmost third of this structure tends to incline downwards, so that its dorsal margin is somewhat convex. Likewise, this region is more extended longitudinally than in Glyptodon. The symphyseal region is shorter than in G. munizi, G. clavipes and Glyptotherium arizonae. Posteriorly, this region ends at approximately a vertical plane passing through the first lobe of $\mathrm{m} 4$, as in Glyptodon and the remaining Glyptotherium species. The ascending ramus is remarkably tall and wide at the alveolar level; it begins at the level of the first lobe of $\mathrm{m} 6$, rising at an angle of about $60^{\circ}$ to $70^{\circ}$ with respect to the occlusal plane. Its anterosuperiormost point coincides with 


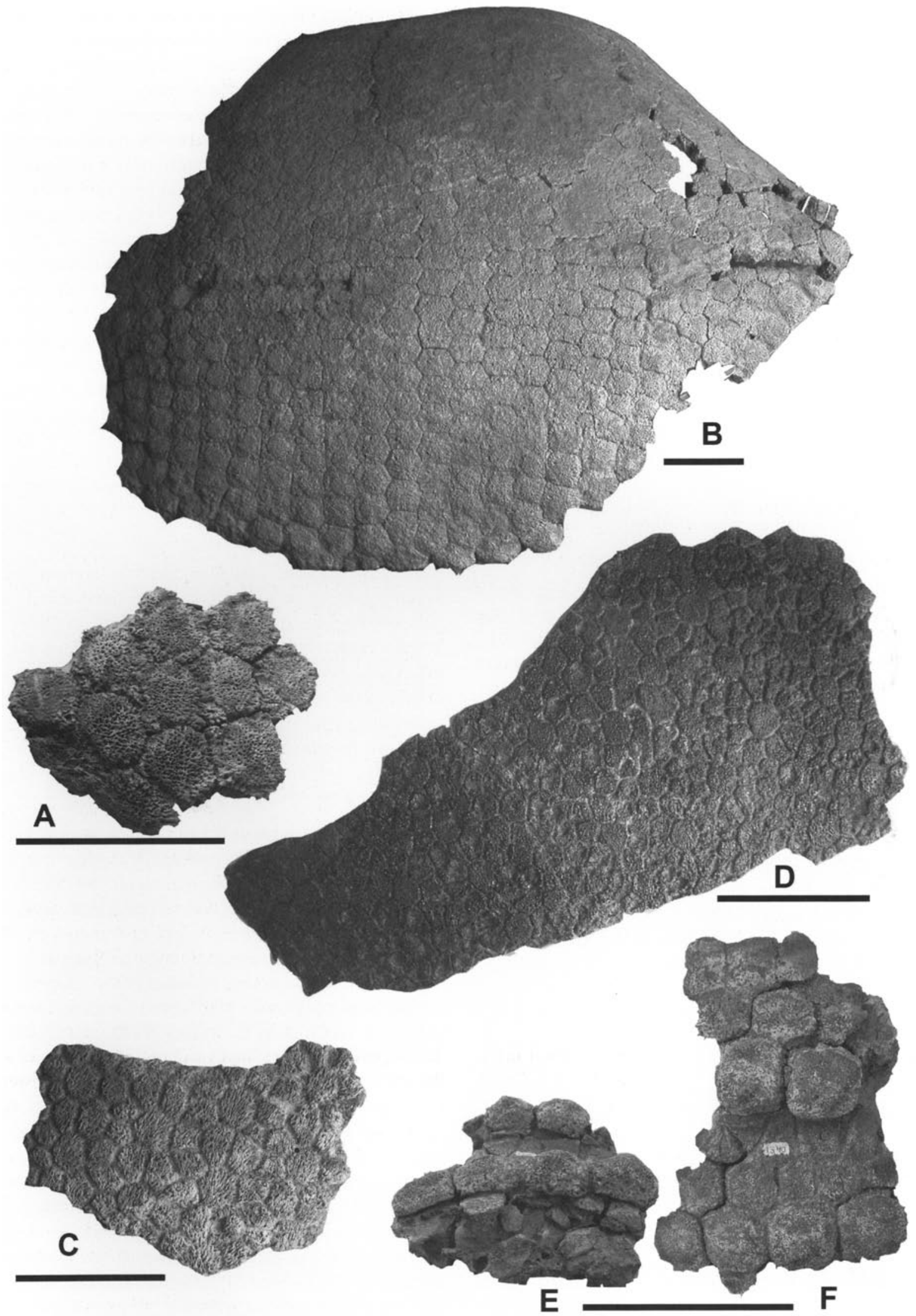

Fig. 3. Glyptotherium cf. cylindricum. A: (CIAAP n/n) articulated osteoderms of a partial cephalic shield in dorsal view (anterior to left). B: (CIAAP $n / n$ ) articulated osteoderms of a partial caparace in left lateral view. C-D: (MCN $\mathrm{n} / \mathrm{n}$ ) aticulated osteoderms of a partial caparace of one specimen, showing the rugose external surface. E-F: (UNEFM 1540) articulated osteoderms of two partial caudal rings, each of them formed by three osteoderm rows; E. posterior and F. external view. - Scale bar $=10 \mathrm{~cm}$. 
the projection of the $\mathrm{m} 5-\mathrm{m} 6$ boundary. The lower half of the anterior margin of the ascending ramus bears a very marked notch delimiting a clearly concave region at the level of the molariforms. This concavity is much less marked in Glyptodon, $G$. arizonae and $G$. floridanum.

Cephalic shield: The preserved fragment of a cephalic shield (UNEFM-CIAAP $n / n$ ) consists of twelve articulated osteoderms (Fig. 3A). The ornamentation of these osteoderms is similar to that of the carapace, only less evident, and the central figure of each osteoderm is somewhat raised with respect to the peripheral figures. Each osteoderm has a central subcircular figure with an extremely rugose dorsal surface and numerous perforations that increase its rugosity. Each central figure is surrounded by a row of poorly developed small peripheral figures. The morphology of these osteoderms is very different from that of Glyptodon, in which most of the cephalic shield is formed by small polygonal osteoderms presenting a smoothly convex dorsal surface with no signs of ornamentation (SOIBELZON et al. 2006: 382).

Carapace: A large articulated portion of the posterolateral region is preserved (UNEFM-CIAAP 578) (Fig. 3B). The dorsal profile is markedly convex in lateral view, as in Glyptotherium cylindricum (AMNH 15548), and somewhat similar to that of the Propalaehoplophorinae Propalaehoplophorus and Cochlops. This characteristic morphology differentiates this taxon from $G l y$ ptodon clavipes and $G$. munizi that have carapaces with greater anteroposterior diameters and less convex dorsal profiles. The region adjacent to the caudal notch is clearly inclined upwards, as described for Glyptotherium cylindricum (GILLETTE \& RAY 1981: 184). This character is absent in Glyptotherium texanum, but present in Glyptotherium arizonae, although the condition is less marked in the latter species. The osteoderms are characterized by a primitive ornamentation pattern, consisting of a circular or subcircular central figure encircled by a row of polygonal peripheral figures, which are always smaller than the central one, as in Glyptodon. However, in contrast with the condition in Glyptodon, in which the exposed surface is almost smooth (AMEGHINO 1889; SOIBELZON et al. 2006), in Glyptotherium the exposed surface is extremely rugose (Figs. 3C, D), with numerous perforations, and the peripheral figures are less symmetrical in some osteoderms. In some portions of the carapace the perforations are more evident and present distinct oblique dorso-ventral orientation.

Caudal rings: Fragments of two associated caudal rings from a region close to the caudal notch are preserved (UNEFM 1540) (Figs. 3E, F). Each ring is formed by three transverse rows of osteoderms, in contrast with G. munizi, G. clavipes, G. texanum, G. floridanum, and $G$. arizonae in which there are only two rows of osteoderms. Each distalmost row is formed by quadrangular osteoderms with clearly convex, very rugose and punctuated exposed surfaces. A small conical prominence occurs at the middle of the posterior margin of each osteoderm, which is morphologically very similar to that of G. floridanum and G. arizonae, and clearly different from that of Glyptodon. In the latter taxon these tubercles are generally much more developed, forming pointed conical structures, similar to bony "spines". The middle row is formed by smaller osteoderms, mostly hexagonal and with a flat or slightly convex dorsal surface, but never as convex as the osteoderms in the distalmost row. The proximalmost row comprises pentagonal osteoderms with the same morphology as that described above, but with plainly flat exposed surfaces. The proximal third of each osteoderm is noticeably thinner, flat and rectangular, representing the articulation with the preceding caudal ring.

\section{Provenance of material}

Most of the material studied comes from archaeological sites containing megafauna, or from latest Pleistocene palaeontological sites. Notwithstanding, in 2006 we found a complete carapace in the northern town of Urumaco, and one of us (OA) saw isolated broken osteoderms in the Paraguaná Peninsula (Fig. 1). Outside Estado Falcón, some other sites (e.g., Lago de Valencia, Maracay, Estado Aragua, A. Jaimes pers. com.) might have $G$. cf. cylindricum among its faunal assemblages, but we have not yet studied the remains.

TaimaTaima: This site is $2.5 \mathrm{~km}$ northwest of TaraTara, Colina Municipality, Falcón State, in an area with "ojos de agua" or ascending spring waters $\left(11^{\circ} 29^{\prime} 57^{\prime \prime} \mathrm{N}\right.$ and $\left.69^{\circ} 31^{\prime} 18^{\prime \prime} \mathrm{W}\right)$. The Pleistocene sediments consist of gray clayey sands arranged in a layer 0.75 to $1 \mathrm{~m}$ thick, overlying a pavement formed by coquinoid sandstone that belongs to the TaimaTaima Member of the Caujarao Formation (upper Miocene). The TaimaTaima fossil bed was described and studied by BRYAN (1979) and GRUHN \& BRYAN (1984), and divided into four units, of which Unit I has the greatest palaeontological significance. The superficial portion of this Unit I, above the current phreatic level, is oxidized, and the lower third was saturated with water at the time of excavation. The top of Unit I is conspicuous due to an evident unconformity that indicates an erosional episode. The remaining paleosoil, with a layer of pebbles and abundant fragmentary fossils, overlies the unconformity. The paleofaunal association at the unconformity between Units I/II forms the third faunal horizon that represents the last evidence of megafauna at the TaimaTaima site. The reddish sands that underlie Unit II are barren. The uppermost stratigraphic unit is a stratum of brown sands, also barren. The age of the fossil-bearing unit (Unit I) was established on the basis of radiocarbon $\left(\mathrm{C}^{14}\right)$ dating of diverse types of samples: TAMERS (1971) 
dated bones and sediment samples, obtaining an age between 14,000 and 12,000 radiocarbon years BP; similarly, GRUHN \& BRYAN (1984), based on the analysis of plant remains, dated it at between $12,580 \pm 150$ and $13,390 \pm 130$ radiocarbon years BP.

Muaco: This site is in the Muaco village, between the Muaco harbour and Carrizal, Colina Municipality, Falcón State, precisely at the location of "ojos de agua" or ascending spring waters $\left(11^{\circ} 28^{\prime} 51^{\prime \prime} \mathrm{N}\right.$ and $69^{\circ} 32^{\prime}$ $\left.41^{\prime \prime} \mathrm{W}\right)$. The site consists of a layer of Pleistocene muddy sediments, 2 to $3 \mathrm{~m}$ thick, overlying Miocene sandstones that belong to the Caujarao Formation. The fossils were found sunk in the mud, above the sandstone (ROYO GómEZ 1960). The age of the fossil-bearing unit has been established at between $14,300 \pm 500$ and 16,375 \pm 400 radiocarbon years before present (OCHSENIUS 1980; ROYo GómEz 1960; Rouse \& CRUXENT 1963).

Cucuruchú: This is located at a low hill near Cucuruchú creek, which drains into the Agua Divina gully, between Curazaito and TaimaTaima, in Colina Municipality, Falcón State, about $200 \mathrm{~m}$ away from the coast line $\left(11^{\circ} 30^{\prime} 10^{\prime \prime} \mathrm{N}\right.$ and $\left.69^{\circ} 30^{\prime} 17^{\prime} ' \mathrm{~W}\right)$. There are several ascending springs around the fossil deposit area. The site consists of a thin layer of fragments of rounded limestone rocks ranging in size from pebbles to cobbles and embedded in a clayey matrix. This layer of fluvial Pleistocene sediments is between a few centimetres and half a metre thick, and it is the main fossil-bearing layer. Above the pebble level there is a massive gray to brown clayey layer with impressions of stems and leaves. Its current thickness is $10 \mathrm{~m}$ but it was probably thicker originally, and is very probably lacustrine in origin. Some fragmentary fossil remains have been found in the lower section of these clays (CRUXENT 1970). The age of the fossil-bearing unit could not be dated reliably, and the results obtained by BRYAN (1973) correspond in all probability to rejuvenated samples $(5,860 \pm 80$ radiocarbon years BP). This age is not consistent with the late Pleistocene faunal association found in this fossil bed.

Quebrada Ocando: This bed is located in the valley formed by the Quebrada Ocando southeast from the Mataruca hamlet, in Colina Municipality, Falcón State $\left(11^{\circ} 25^{\prime} 08^{\prime \prime} \mathrm{N}\right.$ and $\left.69^{\circ} 29^{\prime} 47^{\prime \prime} \mathrm{W}\right)$. The site consists of a layer of rounded limestone fragments ranging in size from pebbles to cobbles, in a matrix of pale yellow Pleistocene clayey sands; it is 1 to $3 \mathrm{~m}$ thick and is the main fossil-bearing layer. No information about the age of the fossil-bearing unit is available.

\section{Discussion}

The phylogenetic history of the Glyptodontinae is peculiar and poorly known at present. The earliest record is represented by Glyptodontidium tuberifer CABRERA, 1944, from the "Araucanian" (late Miocene - early
Pliocene; ca. 8.7 - 3.9 Ma) of Catamarca and Tucumán provinces, Argentina. Another, poorly characterized genus included in this subfamily is Paraglyptodon CASTELLANOS, 1932, from the Pliocene of Argentina; one of the species of this genus ( $P$. chapadmalensis AMEGHINO, 1908) is of biostratigraphical importance as characteristic of the upper Chapadmalalan Stage/Age (ca. 3.5 - 3.2 Ma) (see CIONE \& TONNI 1995b, 2005). Another species recognized is $P$. uquiensis CASTELLANOS (Marplatan; ca. 3.2 - 1.8 Ma), which partly resembles the Pleistocene genus Glyptodon, particularly in skull features (CASTELLANOS 1953).

Although this subfamily has not yet been subject to cladistic analysis, the Glyptodontinae clearly appear to be a natural group. In this sense, the main synapomorphies that support the monophyly of this taxon are the conical osteoderms forming the margins of the carapace, and the presence of secondary hard dentine ramifications in the molariform teeth (SCILLATO-YANÉ et al. 1995; CARlini \& SCIllato-YanÉ 1999). Additional characters include a very constant, rosette-shaped ornamentation pattern and a very solid and thick carapace (see HoffsteTter 1958; PAula Couto 1979). Likewise, the phylogenetic relationships between Glyptodontinae and the other glyptodontid subfamilies (Propalaehoplohorinae, Glyptatelinae, Hoplophorinae, and Doedicurinae) remain uncertain, although some preliminary phylogenetic analyses tentatively place the Glyptodontinae as sister group of the Doedicurinae (see FERNÍCOLA et al. 2002; FERNíCOLA 2005).

According to BOMBIN (1976), FIDALGO \& TONNI (1983), UBILla (1985), SCILlATO-YANÉ et al. (1995), and FARIÑA (1996), the Glyptodontinae seems to have evolved in open habitats with grasslands and steppes. In addition, recent analyses of the hyoid apparatus of Glyptodon (PÉREZ et al. 2000) and the remarkable hypsodonty attained by these Cingulata (FARIÑA \& VIZCAÍNO 2001) suggest a primarily grazing diet.

Already in the early Pleistocene (ca. 1.8 Ma), Glyptodon (the only Glyptodontinae) was one of the most conspicuous taxa within the South American "megafauna", considering the notable frequency of discoveries referable to this subfamily. From a stratigraphical viewpoint, the oldest well-characterized species is Glyptodon munizi, from the Ensenadan of the localities Mar del Plata and the "Toscas" of Rio de La Plata, Buenos Aires province, Argentina (SOIBELZON et al. 2006). According to available magnetostratigraphical information, the sedimentary sequence of the "Toscas" of Río de La Plata ranges between 1.7 and $0.98 \mathrm{Ma}$ (early - middle Ensenadan) (BIDEGAIN 1991). This taxon is morphologically very similar to the most derived species of the genus ( $G$. clavipes and G. reticulatus; see DUARTE 1997; SCILLATOYANÉ et al. 1995; CARLINI \& SCILLATO-YANÉ 1999), although distinguished by less lobation of the first molariform, greater skull elongation and narrowing of the region between the postorbital apophysis and supraoccipital ridge (see SoIBELZON et al. 2006). 
From a biogeographic viewpoint, Glyptodon (Ensenadan - Lujanian) is the genus with the greatest latitudinal range among the Glyptodontidae, with remains found in Argentina (see AMEGHINO 1889; CARLINI \& SCILlato-YANÉ 1999, among others), Paraguay (HoFFSTETTER 1978; CARLINI \& TONNI 2000), Uruguay (UbILla 1996; Ubilla \& PereA 1999; Ubilla et al. 2004), Brasil (see BOMBIN 1976; OLIVEIRA 1999; RANZI 2000, among others), Bolivia (OPPENHEIM 1943; TAKAI et al. 1984; MARSHALL \& SEMPERE 1991; WERDELIN 1991), Peru (Pujos \& SAlas 2004), Ecuador (MARSHALL et al. 1984), and probably Colombia (BOMBIN 1981). Within South America, Glyptodon is scarce in the Amazonian region (see RANZI 2000), but relatively frequent in coastal and Andean regions (PUJOS \& SALAS 2004). Its presence in Central America, especially in Mexico, is uncertain and in need of revision (PAULA COUTO 1979; GILlETTE \& RAY 1981). However, outside of the current Argentine territory, most of the records are only identified to genus level and require urgent revision considering their remarkable latitudinal range (see MARSHALl et al. 1984; UBILla \& PEREA 1999; Oliveira 1999; Pujos \& SAlas 2004; UbILla et al. 2004).

In this sense, the Glyptodontinae is probably the only member of the family that participated in the GABI (GILLETTE \& RAY 1981) and then had a cladogenesis in North America that is represented by several species. The earliest records of Glyptodontinae in North America are ca. 3.9 Ma, from the state of Guanajuato in central Mexico (CARRanZa-CastañedA \& Miller 2004; FLYNN et al. 2005). Notwithstanding, it is possible that another subfamily also participated, the Glyptatelinae, only represented by Pachyarmatherium leiseyi DowING \& WHITE, 1995, which was originally described as a Dasypodidae.

In North America, the only recognized glyptodontine genus is Glyptotherium (Early Pliocene? - Late Pliocene - Late Pleistocene), with a latitudinal distribution ranging from approximately $37^{\circ} \mathrm{N}$ to probably $13-$ $14^{\circ} \mathrm{N}$ (GILLETTE \& RAY 1981; WeBB \& PERRIGO 1984; CZAPLEWSKI 2004). Until the present, all the records with clear species-level identification are restricted to the southern US and Mexico.

From a stratigraphic perspective, the earliest unquestionable record for the genus is represented by Glyptotherium texanum, collected from the 111 Ranch locality (Arizona, US), from sediments dated at approximately $2.6 \mathrm{Ma}$, immediately below the Gauss/Matuyama boundary, and which probably represents the first stages of the migration of these taxa from South to North America (ca. 2.7 Ma; WHITE \& MORGAN 2005; MORGAN \& WHITE 2005; WEBB 2006; but see CARRANZACASTAÑEDA \& MILLER 2004; FLYNN et al.. 2005). The most recent records correspond to Glyptotherium floridanum, whose biochron coincides with the Rancholabrean age (ca. $0.3-0.009 \mathrm{Ma}$ ) (MORGAN \& HULBERT 1995).
In Central America, Glyptotherium arizonae has been reported for the early Pleistocene (early - middle?; Irvingtonian?) of El Salvador (CISNEROS et al. 2001; CISNEROS 2005); however, species identification is still provisional, as the materials comprise isolated osteoderms and three molariforms and have been classified partly on the basis of stratigraphical criteria. WEBB \& PERRIGO (1984) cited the presence of Glyptotherium sp. in the late Pleistocene of Honduras and Panamá, and JACKSON \& FERNANDEZ (2005) identified G. floridanum from Honduras, which thus represents the southernmost record for Central America.

Of the five species recognized as valid by GILLETTE \& RAY (1981), G. cylindricum is, together with G. floridanum and G. mexicanum, one of the species occurring in younger sediments, considering that all are restricted to the Rancholabrean (late Pleistocene).

From an anatomical viewpoint, the more derived species of the genus ( $G$. mexicanum, $G$. floridanum and G. cylindricum) are clearly differentiated from those with earlier records ( $G$. texanum and $G$. arizonae) by the following characteristics: a) G. cylindricum (AMNH 15548 ) and $G$. mexicanum show evident shortening of the dorsal carapace, whereas the dorsal profile becomes very convex in lateral view and the area adjacent to the caudal notch is inclined upwards; b) in G. floridanum (USNM 6071) the rostral area is elongated anteroposteriorly; this morphology becomes quite evident at the prolongation of the predental portion of the palate; c) the angle formed by the palatal plane and the dorsal profile of the skull is less acute (ca. $35^{\circ}$ ); d) the mandible is more gracile, differing from that of $G$. arizonae, which is morphologically more similar to the species of $G l y$ ptodon.

In this context, the remains found in the late Pleistocene of Venezuela, in the localities TaimaTaima, Muaco, Cucuruchú, and Quebrada Ocando, in Falcón State (and which were originally assigned to Glyptodon), clearly correspond to genus Glyptotherium, and thus represent the first record for this genus in South America, thus considerably expanding its distribution to $70^{\circ} \mathrm{W}$ and $11^{\circ} \mathrm{N}$. This genus assignment is based on the following: a) dorsal surface of the dorsal carapace osteoderms very rugose, different from those of Glyptodon, in which they are smoother (see DUARTE 1997; TONNI \& BERMAN 1988; RINDERKNECHT 2000); b) absence of the typical bony "spines" observed in the caudal rings of Glyptodon (see AMEGHINO 1889; SOIBELZON et al. 2006); c) more gracile mandibular horizontal ramus, with predental symphyseal region markedly prolonged anteroposteriorly, and molariform series (particularly m1-m3) morphologically more primitive; d) ventral margin of horizontal ramus subparallel to the molariform series; d) skull markedly elongated anteroposteriorly, and with greater postorbital and bizygomatic diameters; e) rostral area remarkably prolonged forward, particularly the predental portion of the palate. 
On the other hand, the species assignment is somewhat uncertain due to the relatively poor knowledge of G. cylindricum, which is limited to the holotype, the most significant element of which is a dorsal carapace in excellent condition (AMNH 15548). This specimen is characterized by its notable anteroposterior shortening, markedly convex dorsal profile and upward curvature of the region adjacent to the caudal notch (BROWN 1912; GILLETTE \& RAY 1981). One carapace from Taima Taima examined - UNEFM-CIAAP 578 - (Fig. 3B) shows remarkable similarities to that of the type of Glyptotherium cylindricum (see GILLETTE \& RAY 1981: fig. 87). Likewise, the upper molariform series corresponding to specimens from Venezuela are morphologically very similar to those figured by GILLETTE \& RAY (1981: 60) as belonging to G. cylindricum. With respect to the skull, the notable elongation of the rostral area, similar to the condition in Late Pleistocene Glyptotherium species, is evident.

From a biogeographic perspective, the distribution of Glyptotherium supports the hypothesis of rapid entrance and dispersion of Glyptodontinae into North America during the GABI, given that the earliest unquestionable records referred with certainty to this genus (but see CARRANZA-CASTAÑEDA \& MILlER 2004; FLYNN et al. 2005) are ca. 2.6 Ma old (G. texanum), coincident with the first evidence (or shortly after) of massive immigration from South America after the formation of a continuous and stable land passage (ca. 2.7 Ma) (Fig. 4). These earliest records of $G$. arizonae extend as far north as $37^{\circ} \mathrm{N}$. During the Pleistocene, Glyptotherium expanded its longitudinal distribution, until it ranged from $110^{\circ} \mathrm{W}$ to $80^{\circ} \mathrm{W}$ (CZAPLEWSKI 2004). Likewise, it dispersed southward into Central America during its cladogenesis, as indicated by records in El Salvador (Irvingtonian?, see CISNEROS 2005) and the late Pleistocene of Honduras and Panamá (WEBB \& PERRIGo 1984). In this biogeographic context, the occurrence of Glyptotherium cf. G. cylindricum in the latest Pleistocene of the northern extreme of South America (Fig. 4) can be interpreted as a new case of re-entrance of a group that emigrated from South America and diversified in North America, as has already been proposed for the pampatheriid Cingulata (SCILLATOYANÉ et al. 2005). The migratory processes manifested by these Cingulata could be associated with the existence of some kind of low land "corridors" that might have connected the Florida peninsula with Mexico, and/ or Central America and the northern extreme of South America (MORGAN \& HULBERT 1995; WEBB 2006). These low land "corridors" would have developed during the LGM (Last Glacial Maximum) when the sea level dropped up to 120-140 metres below present sea level (RABASSA et al. 2005). Because the Pliocene vertebrate record of northern South America is so poor, we cannot be sure, if the differentiation of Glyptotherium occurred before, with later migration to North America, or vice versa; only new discoveries in northern South

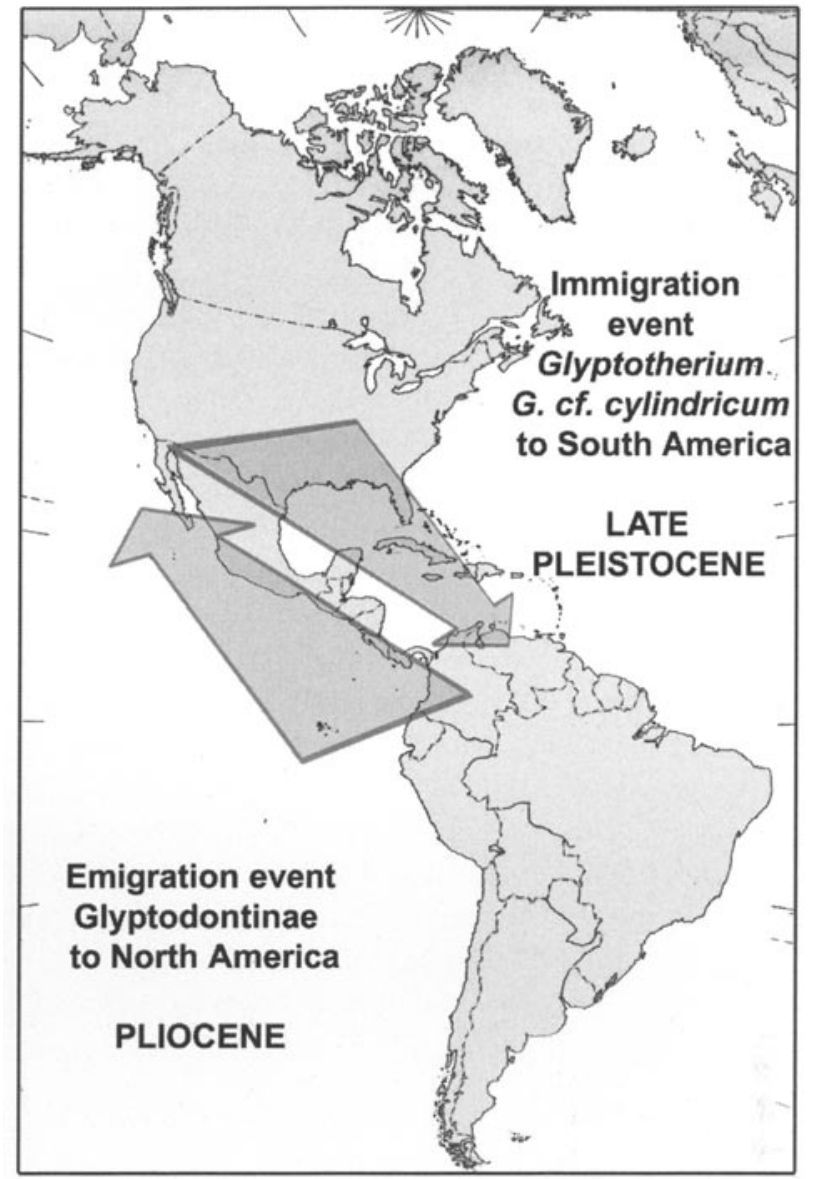

Fig. 4: Main dispersal events of Glyptodontinae between South America and North America: emigration event to North America (Late Pliocene) of a Glyptodontinae species (Glyptotherium? sp.) and subsequent differentiation of Glyptotherium texanum and immigration event from North America (late Pleistocene) of a Glyptotherium species, probably $G$. cf. cylindricum and its dispersal to northern South America.

America in sediments older, but close to $2.7 \mathrm{Ma}$, could clarify this situation. In this biogeographic context, CARRANZA-CASTAÑEdA \& Miller (2004) and FlynN et al. (2005) have reported the presence of the genus Glyptotherium in central Mexico, exhumed in sediments dated at approximately $3.9 \mathrm{Ma}$. Unfortunately, this early Blancan glyptodont material consists primarily of isolated osteoderms (not illustrated), and consequently its generic identification is uncertain to us; it would not be surprising, if this early glyptodontine species record is shown to be related with the new glyptodont we described from the Codore Formation (Pliocene), Falcon State, Venezuela (see CARLINI et al. 2008).

\section{Conclusions}

1. The genera Glyptodon OWEN, 1839, and Glyptotherium OSBORN, 1903, are clearly differentiable taxa. The main distinguishing features are in the 
skull-mandible, morphology of the molariforms and osteoderms of the carapace and caudal shield.

2. Biochronologically, the earliest unquestionable records of Glyptotherium are about $2.6 \mathrm{Ma}$ old ( $G$. texanum), whereas the earliest Glyptodon records ( $G$. munizi) occur at the early Pleistocene (ca. 1.7 $0.98 \mathrm{Ma}$ ).

3. The presence of Glyptotherium $\mathrm{cf}$. G. cylindricum in the latest Pleistocene of northernmost South America (Falcón State, Venezuela) suggests a re-entrance of these Glyptodontinae during the late Pleistocene, probably associated with a biogeographical "corridor" that formed during one of the later glacial periods.

4. The assignment of the remains studied to Glyptotherium cf. G. cylindricum is based primarily on similarities observed in the morphology of the carapace and molariforms, but the relatively poor knowledge of this taxon makes this a tentative assignment. Alternatively, the specimens from Venezuela could correspond to Glyptotherium floridanum, a species with an apparently later record (late Rancholabrean), and latitudinal distribution reaching about $33^{\circ} \mathrm{N}$.

5. All the records dated in Venezuela are ca. $14 \mathrm{ka}$, and often associated with some kind of human activity (e.g., TaimaTaima site).

\section{Acknowledgments}

We wish to thank IPC (Instituto del Patrimonio Cultural de Venezuela) for permission to study important glyptodont materials that are part of the national patrimony of the República Bolivariana de Venezuela; authorities of UNEFM (Universidad Nacional Experimental Francisco Miranda, Coro), $\mathrm{H}$. Moreno and M. Matjushin from MCN (Museo de Ciencias de Caracas), I. Alfonzo from UCV (Universidad Central de Venezuela), for granting access to the collections under their care and for their support during the research; G.J. ScillatoYané for his valuable suggestions on an early version of the ms; the two reviewers, D.D. Gillette and G. Morgan, for their valuable comments and suggestions; R. Sánchez and A. Pulgar for their assistance during visits to museums and fieldwork; and C. Morgan for the English translation of the manuscript. Particularly, we wish to thank A. Jaimes from CONATEL for interesting discussions about archaeological sites with megafauna in Venezuela. Finally, AAC and AEZ especially thank M.R. Sánchez-Villagra and O. Aguilera for the invitation to contribute to this volume. This research was partially funded by grant PICT-R 074 (G3) and UNLP-FCNYM $\mathrm{N}-154$ to AAC and was otherwise supported by the University of Zürich.

\section{References}

Aguilera, O. 2006. Tesoros Paleontológicos de Venezuela: El Cuaternario del Nordeste del Estado Falcón. - 120 p., Caracas (Editorial Arte).
AMEGHINO, F. 1889. Contribución al conocimiento de los mamíferos fósiles de la República Argentina. - Actas de la Academia Nacional de Ciencias de Córdoba 6: 1-1027.

AMEGHINO, F. 1908. Las formaciones sedimentarias de la región Litoral de Mar del Plata y Chapalmalal. - Anales del Museo Nacional de Buenos Aires 3 (10): 343-428

BIDEGAIN, J.C. 1991. Sedimentary development, magnetostratigraphy and sequence of events of late Cenozoic in Entre Ríos and surrounding areas in Argentina. - 128 p., Paleogeophycis \& Geodynamics, Department of Geology and Geochemistry. Sweden (Stockholm University).

BoCQUENTIN-VILlanUeVA, J. 1982a. Notas sobre la fauna del Pleistoceno superior de Taima-Taima depositada en el Museo del Hombre de Coro, Estado Falcón, Venezuela. - Acta Científica Venezolana 33: 479-487.

BOCQUENTIN-VILLANUEVA, J. 1982b. Informe sobre las excavaciones del sitio de Cucuruchú La Playa. - Centro de Investigaciones en Arqueología, Antropología y Paleontología, UNEFM: 3.

Bombin, M. 1976. Modelo Paleoecológico-evolutivo para o Neoquaternário da região da Campanha- Oeste do Rio Grande do Sul (Brasil). A Formação Touro Passo, seu conteúdo fossilífero e a pedogénese pós-deposicional. - Comunicações do Museu de Ciências da PUCRGS 15: 1-90.

BRown, B. 1912. Brachyostracon, a new genus of glyptodonts from México. - American Museum of Natural History Bulletin, 31 (17): $167-177$.

BRYAN, A.L. 1973. Paleoenviroments and cultural diversity in Late Pleistocene South America. - Quaternary Research 3: 237256.

BRYAN, A.L. 1979. The contribution of J. M. CRUXENT to the study of the Paleo-Indian problem in the New World. - Homenaje a José M. CRuXENT: 63-75, Caracas (Centro de Estudios Avanzados del IVIC).

BURMEISTER, H. 1864. Noticias preliminares sobre las diferentes especies de Glyptodon en el Museo Público de Buenos Aires. Anales del Museo Público de Buenos Aires 1 (1): 71-85.

Cabrera, A. 1944. Los Gliptodontoideos del Araucaniano de Catamarca. - Revista del Museo de La Plata (Nueva Serie) 3 (15): 5 76.

CARLINI, A.A. \& SCIllato-YANÉ, G.J. 1999. Evolution of Quaternary Xenarthrans (Mammalia) of Argentina. - In: RABASSA, J. \& SALEMME, M., eds., Quaternary of South America and Antarctic Peninsula 12: 149-175.

Carlini, A.A. \& TonNi, E.P. 2000. Mamíferos fósiles del Paraguay. 108 p., La Plata, Argentina (Cooperación técnica ParaguayoAlemana).

Carranza-Castañeda, O. \& Miller, W.E. 2004. Late Tertiary terrestrial mammals from Central Mexico and their relationship to South American immigrants. - Revista Brasileira de Paleontologia 7 (2): 249-261.

CASAMIQUela, R.M. 1979. An interpretation of the fossil vertebrates of TaimaTaima site. - In: Taima Taima: Final report on the 1976 excavations. - In: OCHSENIUS, C. \& GRUHN, R., eds., Monografías Científicas 3: 59-76, Coro, Venezuela (Programa CIPICS, Universidad Nacional Experimental Francisco de Miranda).

Castellanos, A. 1932. Nuevos géneros de gliptodontes en relación con su filogenia. - Physis 11 (38): 92-100.

Castellanos, A. 1953. Descripción de restos de Paraglyptodon uquiensis n. sp. de Uquía (Senador Pérez), Jujuy. - Memorias del Museo de Entre Ríos 32 (Paleontología): 1-32.

ConE, A.L. \& TONNI, E.P. 1995a. Bioestratigrafía y cronología del Cenozoico de la región Pampeana. - In: AlBerd, M.T.; LEONE, G. \& TONNI, E.P., eds., Evolución biológica y climática de la región Pampeana durante los últimos cinco millones de años. Un ensayo de correlación con el Mediterráneo occidental. - Museo Nacional de Ciencias Naturales, Madrid, Consejo Superior de Investigaciones Científicas, Monografías CSIC 12: 47-74. 
CIONE, A.L. \& TONNI, E.P. 1995b. Chronostratigraphy and "Land mammals ages" in the Cenozoic of Southern South America: principles, practices and the "Uquian" problem. - Journal of Paleontology 69: 135-169.

Crone, A.L. \& TONNI, E.P. 2001. Correlation of Pliocene to Holocene southern South American and European vertebrate-bearing units. - In: ROOK, L. \& TORRE, D., eds., Neogene and Quaternary continental stratigraphy and mammal evolution. - Bolletin Societa Paleontologia Italiana 40 (2):167-173.

CIONE, A.L. \& TONNI, E.P. 2005. Bioestratigrafía basada en mamíferos del Cenozoico Superior de la provincia de Buenos Aires, Argentina. - 16. Congreso Geologico Argentino, Relatorio: $183-200$.

Cisneros, J.C.; ZURITA, A.E.; Aguilar, D.H. \& ROMERO, M.R. 2001. Nuevos materiales de Glyptodontidae en el Neógeno de El Salvador. - Ameghiniana (Resúmenes) 38 (4): $31 \mathrm{R}$.

CisNeros, J.C. 2005. New Pleistocene vertebrate fauna from El Salvador. - Revista Brasileira de Paleontología 8 (3): 239-255.

COPE, E. 1889. The Edentata of North America. - American Naturalist 23: 657-664.

CRUXENT, J.M. 1967. El Paleo-indio en Taima-Taima, estado Falcón, Venezuela. - Acta Científica Venezolana, Suplemento 3: 3-17.

CruXENT, J.M. 1970. Projectile points with Pleistocene mammals in Venezuela. - American Antiquity 44: 223-226.

CZAPLEWSKI, N.J. 2004. A glyptodont (Mammalia: Xenarthra) from northern Oklahoma. - Oklahoma Geology Notes 64: 4-10.

DowING, K.F. \& WhITE, R, 1995. The cingulates (Xenarthra) of the Leisey Shell Pit local fauna (Irvingtonian), Hillsborough County, Florida. - Bulletin of the Florida Museum of Natural History 37 II (12): 375-396.

DuarTE, R.G. 1997. Gliptodontes del Pleistoceno tardío de Aguas de las Palomas, Campo de Pucará, Catamarca, Argentina. Variaciones morfológicas del caparazón de Glyptodon reticulatus OWEN, 1845. - Ameghiniana 34 (3): 345-355.

FARIÑA, R.A. 1996. Limb bone strength and habits in large glyptodonts. - Lethaia 28 (3): 189-330.

FARIÑA, R.A. \& VIZCAÍNO, S.F. 2001. Carved teeth and strange jaws: How glyptodonts masticated. - Acta Palaeontologica Polonica 46 (2): 219-234.

FERníCOLA, J.C.; FARIÑA, R.A. \& VizCAínO, S.F. 2002. Análisis filogenético de la familia Glyptodontidae BURMEISTER, 1879. - 1 . Congreso Latinoamericano de Paleontología de Vertebrados, resúmenes: $32-33$.

FERnf́COLA, J.C. 2005. Análisis filogenético de la familia Glyptodontidae GRAY. - Ameghiniana 42 (4): 27R.

FIDALGO, F. \& TONNI, E.P. 1983. Geología y paleontología de los sedimentos encauzados del Pleistoceno tardío y Holoceno en Punta Hermengo y Arroyo Las Brusquitas (Partido de General Alvarado y General Pueyrredón, Provincia de Buenos Aires). Ameghiniana 20 (3/4): 281-296.

Flynn, J.; Kowallis, B.J.; Nuñez, C.; CaRranza-Castañeda, O.; MillaR, W.E.; Swisher, C.C. \& LindSAy, E. 2005. Geochronology of Hemphillian-Blancan aged strata, Guanajuato, Mexico, and implications for timing of the Great American Biotic Interchange. - Journal of Geology 113: 287-307.

GILLETTE, D.D. \& RAY, C.E. 1981. Glyptodonts of North America. Smithsonian Contributions to Paleobiology 40: 1-251.

GRAY, J.E. 1869. Catalogue of carnivorous, pachydermatous, and edentate Mammalia in the British Museum. - 398 p., London (Printed by order of the Trustees, British Museum).

GRUHN, R. \& BRYAN, A.L. 1984. The record of Pleistocene Megafaunal extinction at Taima Taima, Northern Venezuela. - In: MARTIN, P.S. \&. KLEIN, R.G., eds., Quaternary Extinctions: A Prehistoric Revolution: 128-138, Tucson.

HoffstetTeR, R. 1958. Xenarthra. - In: Piveteau, J., ed., Traité de Paléontologie 6 (2): 535-636.

HOFFSTETTER, R. 1978. Une faune de Mammifères pléistocènes au Paraguay. - Comptes Rendus Sommaires des Séances de la Societé Géologique de France 1: 32-33.
ILLIGER, C. 1811. Prodromus Systematis Mammalium et Avium Additis Terminis Zoographicis Utriusque Calssis. - 301 p., Berlin (C. Salfeld).

JACKSON, D.R. \& FERNÁNDEZ, E. 2005. A small Pleistocene mammalian megafauna from southern Honduras. - In: Cenozoic vertebrates of the Americas. Papers to honor S. DAVID WEBB. - Florida Museum of Natural History Bulletin 45 (4): 261-269.

KARSTEN, H. 1886. Geologie de l'ancienne Colombie bolivarienne, Venezuela, Nouville Grenade et Ecuador. - 62p., Berlin (Friedlander).

LYDEKKER, R. 1894. Contribution to the knowledge of the fossil vertebrates of Argentina. 2. The extinet edentates of Argentina. Anales del Museo de La Plata (Paleontología) 3: 1-118.

MARShall, L.; BerTa, A.; HoffSTetTer, R.; PAscual, R.; Reig, O.; BOMBIN, M. \& MONES, A. 1984. Mammals and stratigraphy: geochronology of the continental mammal-bearing Quaternary of South America. -- Palaeovertebrata, Mémoire Extraordinaire: $1-76$.

Marshall, L.G. \& Sempere, T. 1991. The Eocene Pleistocene vertebrates of Bolivia and their stratigraphic context: a review. - In: SUAREZ-SORUCO, R., ed., Fósiles y Facies de Bolivia, Vol. I Vertebrados (3-4): 631-652.

MORGAN, G.S. \& HULBERT, R.C. 1995. Overview of the Geology and vertebrate biochronology of the Leisey Shell Pit local fauna, Hillsborough County, Florida. - In: HULBERT, R.C. Jr.; MORGAN, G.S. \& WEBB, S.D., eds., Paleontology and geology of the Leisey Shell Pits, early Pleistocene of Florida. - Bulletin of the Florida Museum of Natural History 37 (1): 1-92.

MORGAN, G.S. \& WHITE, R.S. 2005. Miocene and Pliocene vertebrates from Arizona. - New Mexico Museum of Natural History and Science Bulletin 29: 115-136.

OCHSENIUS, C. 1980. Cuaternario en Venezuela: Introducción a la Paleontología en el Norte de Sudamérica. - 37 p., Venezuela (Cuadernos Falconianos, Ediciones UNEFM).

OLIVEIRA, E.V. 1999. Quaternary vertebrates and climates of southern Brazil. - In: RABASSA, J. \& SALEMME, M., eds., Quaternary of South America and Antarctic Peninsula 12: 61-73.

OPPENHEIM, V. 1934. The fossiliferous basin of Tarija, Bolivia. - Journal of Geology 51 (8): 548-555.

OSBORN, H.F. 1903. Glyptotherium texanum, a new glyptodont, from the lower Pleistocene of Texas. - Bulletin of the American Museum of Natural History 19 (17): 491-494.

PASCUAL, R. \& ORTIZ-JAUREGUIZAR, E. 1990. Evolving climates and mammal faunas in Cenozoic South America. - Journal of Human Evolution 19: 23-60.

Pascual, R.; Ortiz-Jaureguizar, E. \& PRADO, J.L. 1996. Land mammals: paradigm for Cenozoic American geobiotic evolution. Münchner Geowissenschaftliche Abhandlungen 30: 265-319.

Pascual, R. \& WebB, S.D. (Conveners) 1989. Late Cenozoic mammals: dispersal between Americas. - Fifth International Theriological Congress, Rome, Symposium (S9), Abstracts of papers and posters 1: $260-291$

Paula Couto, C. 1979. Tratado de Paleomastozoologia. - 590 p., Río de Janeiro (Academia Brasileira de Ciências).

PéreZ, L.M.; SCILlato-Yané, G.J. \& VizCaíno, S.F. 2000. Estudio morfofuncional del aparato hiodeo de Glyptodon cf. clavipes (Cingulata: Glyptodontidae). - Ameghiniana 37 (3): 293-299.

Pujos, F. \& SALAs R. 2004. A systematic reassessment and paleogeographic review of fossil Xenarthra from Peru. - Bulletin Institute Françaises d'Études Andines 33 (2): 331-377.

Rabassa, J.; Coronato, A.M. \& Salemme, M. 2005. Chronology of the Late Cenozoic Patagonian glaciations and their correlation with biostratigraphic units of the Pampean region (Argentina). In: RABASSA, J. \& CARLINI A.A., eds., Quaternary paleontology and biostratigraphy of southern South America. - Journal of South American Earth Sciences 20 (1/2): 81-103.

Ranzi, A. 2000. Paleoecologia da Amazônia. Megafauna do Pleistoceno. - 101 p., Brasil (Editorial de la Universidade Federal de Santa Catarina). 
RINDERKNECHT, A. 2000. Estudios sobre la familia Glyptodontidae GRAY, 1869. II. Variación morfológica en la coraza de Glyptodon sp. juvenil (Mammalia, Cingulata). - Revista de la Sociedad Uruguaya de Geología 3 (7): 32-35.

Rouse, I. \& CRUXENT, J.M. 1963. Recientes datos sobre fechas arqueológicas por el método de $\mathrm{C} 14$ en el Occidente de Venezuela. - Acta Científica Venezolana 1: 3-10.

RoYo GómEZ, J. 1960. Característica paleontológicas y geológicas del yacimiento de vertebrados de Muaco, estado Falcón, con industria lítica humana. - Boletín de Geología, Caracas 2 (3): 501 505.

Scillato-Yané, G.J.; Carlini, A.A.; TonNI, E.P. \& Noriega, J.I. 2005. Palaeobiogeography of the late Pleistocene pampatheres of South America. - In: RABASSA, J. \& CARLINI, A.A., eds., Quaternary paleontology and biostratigraphy of southern South America. - Journal of South American Earth Sciences 20 (1/2): 131138.

Scillato-Yane, G.J.; Carlini, A.A.; Vizcaíno, S.F. \& OrTiz-JaUREguIZAR, E. 1995. Los Xenarthros. - In: Alberdi, M.T.; LEONE, G. \& TONNI, E.P., eds., Evolución biológica y climática de la región Pampeana durante los últimos cinco millones de años. Un ensayo de correlación con el Mediterráneo occidental. - Museo de Ciencias Naturales, Consejo de Investigaciones, Madrid, Monografías CSIC 12: 183-209.

SMITH, D.L. 1985. Caribbean plate relative motions (Chapter 2). - In: STEHLI, F.G. \& WEBB, S.W., eds., The Great American Biotic Interchange: 17-48, New York (Plenum Press).

SotBelzon, E.; ZURITA, A.E. \& CARLINI, A.A. 2006. Glyptodon munizi AMEGHINo (Mammalia, Cingulata, Glyptodontidae): redescripción y anatomía. - Ameghiniana 43 (2): 377-384.

TAKaI, F.; Mizuno, T.; IWASAKI, K.; TANAKA, K. \& Yoshida, A. 1982. Tarija mammal-bearing Formation in Bolivia. - The Research Institute of Evolutionary Biology, Tokyo 3: 1-72.

TAMERS, M. 1971. IVIC Natural Radiocarbon Measurements VI. Radiocarbon 13: 32-44.

TONNI, E.P. \& BERMAN, W. 1988. Sobre dos especies de Glyptodon (Mammalia, Cingulata) del Pleistoceno tardío de la provincia de Buenos Aires. Su importancia bioestratigráfica. - 2. Jornadas Geológicas Bonaerenses, Actas: 109-116

Tonni, E.P.; Alberdi, M.T.; Prado, J.L.; BARGo, S. \& Cione, L.A. 1992. Changes of mammal assemblage in the pampean region (Argentina) and their relation with the Plio-Pleistocene boundary. - Palaeocology, Palaeogeography, Palaeoclimatology 95: 179-194.

UBiLla, M. 1985. Mamíferos fósiles, geocronología y paleoecología de la Formación Sopas (Pleistoceno Superior) del Uruguay. Ameghiniana 22 (3/4): 185-196.
UBILlA, M. 1996. Paleozoología del Cuaternario continental de la cuenca norte del Uruguay: Biogeografía, cronología y aspectos climático-ambientales. - Doctoral Thesis. Universidad de la República Uruguay, - 232 p. (unpublished).

UBILla, M. \& PEREA, D. 1999. Quaternary vertebrates of Uruguay: A biostratigraphic, biogeographic and climatic overview. - In: RABASSA, J. \& SALEMME, M., eds., Quaternary of South America and Antarctic Peninsula 12: 75-90.

Ubilla, M.; Perea, D; Aguilar, C.G. \& Lorenzo, N. 2004. Late Pleistocene vertebrates from northern Uruguay: tools for biostratigraphic, climatic and environmental reconstruction. - Quaternary International 114: 129-142.

WeBB, S.D. 1985. Late Cenozoic mammal dispersal between the Americas. - In: STEHLI, F.G. \& WeBB, S.W., eds., The Great American Biotic Interchange: 357-386, New York (Plenum Press).

WEBB, S.D. 2006. The Great American Biotic Interchange: patterns and processes. - Annals of the Missouri Botanical Garden 93 (2): 245-257.

WebB, S.D. \& PeRrigo, S.C. 1984. Late Cenozoic vertebrates from Honduras and El Salvador. - Journal of Vertebrate Paleontology 4 (2): 237-254.

WERDELIN, L. 1991. Pleistocene vertebrates from Tarija, Bolivia in the collections of the Swedish Museum of Natural History. - In: SUAREZ-SORUCO, R., ed., Fósiles y Facies de Bolivia, Vertebra$\operatorname{dos} 1(3 / 4): 673-684$.

WHITE, R.S. \& MORGAN, G.S. 2005. Arizona Blancan vertebrate faunas in regional perspective. - In: MCCORD, R.D., ed., Vertebrate palaeontology of Arizona. - Mesa Sonthwest Museum Bulletin 11: 117-138.

Woodburne, M.O.; Cione, A.L. \& TOnNi, E.P. 2006. Central American provincialism and The Great American Biotic Interchange. - In: Carranza-Castañeda, O. \& Lindsay, E.H., eds., Advances in late Tertiary vertebrate paleontology in Mexico and the Great American Biotic Interchange. - Universidad Nacional Autónoma de México, Instituto de Geología and Centro de Geociencias, Publicación Especial 4: 73-101.

WoOdBuRNE, M.O. \& SWISHER, C.C. 1995. Land-mammals high-resolution geochronology, intercontinental overland dispersals, sea level, climate and vicariance. - In: BERGGREN, W.A., ed., Geochronology, Time Scales and Global Stratigraphic Correlation. - SEPM Special Publication 54: 335-364.

Manuskripteingang / manuscript received 14. 6. 2007; Manuskriptannahme / manuscript accepted 18. 3. 2008. 